\title{
Ecophysiological responses of two closely related epigean and hypogean Niphargus species to hypoxia and increased temperature: Do they differ?
}

\author{
Tatjana Simčič (i] ${ }^{1 *}$ and Boris Sket (10 ${ }^{2}$ \\ ${ }^{1}$ Department of Organisms and Ecosystems Research, National Institute of Biology, Večna pot 111, SI-1000 Ljubljana, Slovenia \\ ${ }^{2}$ Biotechnical Faculty, University of Ljubljana, Večna pot 111, SI-1000 Ljubljana, Slovenia
}

\begin{abstract}
Ecological performance of animals depends on physiological and biochemical processes that are adjusted to the environment. The responses to hypoxia or anoxia have been frequently studied in subterranean aquatic organisms in order to find potential adaptations to restrict oxygen conditions occurring in the underground habitats. However, some previous studies have compared phylogenetic distant epigean and hypogean species or the epigean and hypogean populations of the same species due to little chance to compare closely related epigean and hypogean species. Therefore, in this study, we compared the effects of exposure to hypoxia, followed by reoxygenation, and increased temperature on oxygen consumption, potential metabolic activity, and antioxidant activities in closely related epigean and hypogean species: Niphargus zagrebensis and $N$. stygius. Oxygen consumption of $N$. stygius increased similarly during post-hypoxic recovery at 10 and $20^{\circ} \mathrm{C}$ (approx. 5-times), while $N$. zagrebensis increased its oxygen consumption for 9.7 and 4.4-times at 10 and $20^{\circ} \mathrm{C}$, respectively. We observed higher exploitation of metabolic potential for current oxygen consumption during reoxygenation in $N$. zagrebensis than $N$. stygius. Exposure to hypoxia and subsequent reoxygenation at $20^{\circ} \mathrm{C}$ increased catalase (CAT) activity in N. stygius, but not in $N$. zagrebensis. We observed increased glutathione reductase activity in both Niphargus species. We concluded that respiratory and antioxidant responses to severe hypoxia and increased temperature differed between closely related epigean and hypogean Niphargus species. Hypogean Niphargus species possess physiological and biochemical characteristics that are advantageous in temperature stable subterranean environments which support inhabiting of species that have low energetic demands, while epigean Niphargus species can successfully inhabit specific surface habitats.
\end{abstract}

Keywords: Niphargus stygius, Niphargus zagrebensis, hypoxia adaptation, temperature, metabolic activity Received 19 November 2020; Revised 13 March 2021; Accepted 13 March 2021

Citation: Simčič, T., Sket, B., 2021. Ecophysiological responses of two closely related epigean and hypogean Niphargus species to hypoxia and increased temperature: Do they differ? International Journal of Speleology, 50(2), 111-120.

https://doi.org/10.5038/1827-806X.50.2.2369

\section{INTRODUCTION}

Survival, growth and reproduction of organisms depend on physiological and biochemical processes that are adjusted to the environment. Aquatic arthropods differ in tolerance to hypoxia or anoxia. Many species, including numerous crustaceans, exhibit oxygen debts that are repaid upon return to normoxia, but other invertebrates do not (Herreid, 1980; Ellington, 1983; Zou et al., 1996). Oxygen debt, i.e., the additional oxygen consumption by the animal in the recovery period from anaerobic stress, is generally interpreted as needed in order to meet the increased energy demands for disposal of end products, including oxidation of anaerobic end products for energy, converting end products into storage products, such as glycogen, and regenerating the phosphagen and ATP stores depleted during severe hypoxia (Herreid, 1980).

Many aquatic subterranean organisms have to cope with periodic oxygen depletion in their habitats with sometimes rapid switches from normoxia to hypoxia or even anoxia. Numerous previous studies reported that hypogean species are better adapted to low oxygen content and are better equipped to remain aerobic under hypoxia than epigean ones (Hervant et al., 1995, 1996, 1997b, 1998). Nevertheless, Culver \& Poulson (1971) pointed out 
that phylogenetic effects should be taken into account when comparing the biological responses of epigean and hypogean species. Unfortunately, there is little opportunity to compare closely related epigean and hypogean species. Therefore, an alternative approach comparing biological traits among epigean and hypogean populations of the same species has been used (Biswas, 1991; see review of Malard \& Hervant, 1999). For example, the locomotory and ventilatory activities, oxygen consumption, and the intermediary and energy metabolism modifications of a spring and a cave population of the aquatic amphipod crustacean Gammarus minus Say were investigated in normoxia, severe hypoxia $\left(\mathrm{P}_{\mathrm{O} 2}<0.03 \mathrm{kPa}\right)$, and subsequent recovery to compare the reactions of both populations to these experimental conditions, and the degree of adaptation to hypoxia (Hervant et al., 1999a). Despite their different origins, both populations of $G$. minus presented identical responses in all experimental conditions. Thus, it was assumed that a high resistance to hypoxia is not general characteristic of hypogean organisms but is more related to oxygen availability of particular subterranean habitats (Hervant \& Malard, 2019).

In Slovenia, genus Niphargus (Amphipoda, Niphargidae) is represented by closely related stygobiotic Niphargus stygius (Schioedte) and semisubterranean Niphargus zagrebensis S. Karaman that invaded into epigean waters from the subterranean habitats (Karaman, 2019). Both species are morphologically similar since $N$. stygius is not strongly troglomorphic, while $N$. zagrebensis is considered as a member of an epigean species group exhibiting the same degree of a fictitious troglomorphy (Sket, 2008). This distribution of species gives us a unique opportunity to compare the responses of both species to severe hypoxia and subsequent recovery in normoxia in order to test the previous findings obtained in distantly related species or the epigean and hypogean populations of the same species.

Besides the immediate harmful effect of anaerobiosis, an increased production of reactive oxygen species (ROS) occurs during reoxygenation due to the recovery of activity of the mitochondrial respiratory chain (Hervant \& Malard, 2019). Due to the damaging effects of ROS overproduction animals have developed both non-enzymatic and enzymatic antioxidant mechanisms. To prevent oxidative stress, animals developed anti-oxidative enzymes, including catalase (CAT) and glutathione reductase (GR) (Lushchak et al., 2001; Lushchak \& Bagnyukova, 2006; Issartel et al., 2009; Lawniczak et al., 2013; Vranković et al. 2017). CAT is a very important enzyme in protecting the cell from oxidative damage by ROS, and it has one of the highest turnover numbers of all enzymes. It catalyzes the decomposition of hydrogen peroxide to water and oxygen (Zamocky et al., 2008). GR is the enzyme critical for the reduction of oxidized form of glutathione (GSSG) responsible for maintaining the supply of reduced glutathione (GSH) involved in neutralization of free radicals (Couto et al., 2016). Moreover, oxygen content has been reported as an environmental factor that correlated to CAT activity and GSH content in zebra mussel (Dreissena polymorpha (Pallas)) from the two ecosystems (Wojtal-Frankiewicz et al., 2017). Previous study on the groundwater crustacean Niphargus rhenorhodanensis Schellenberg revealed an overactivation of superoxide dismutase (SOD) and glutathione peroxidase (GPx) activities after exposure to drastic variations in oxygen level compared to the control group (Lawniczak et al., 2013), but information about the antioxidant responses of the closely related epigean Niphargus species is still lacking.

While the basis of hypoxia and temperature as interlinked stressors in aquatic organisms has been proven (Pörtner \& Knust, 2007; Pörtner, 2010), increased temperature was also included in the present study. Because physiological and biochemical rates of ectothermic organisms are highly temperaturedependent (Hochachka \& Somero, 2002), their behavioural and ecological performance, and even fitness, can be influenced by body temperature (Huey $\&$ Kingsolver, 1989). The increase in temperature stimulates all metabolic processes in accordance with known thermodynamic principles. For example, it enhances oxygen consumption and, therefore, may increase ROS production as side products of intensified metabolism, resulting in oxidative stress (Lushchak, 2011). Moreover, higher thermal sensitivity of hypogean $N$. stygius than epigean $N$. zagrebensis that resulted in increased oxygen consumption as a consequence of stress response (Simčič \& Sket, 2019) could enhance ROS production in subterranean species at increased temperatures.

An animal's energy demand is usually quantified by its metabolic rate. Measurement of the entire organism's oxygen consumption gives meaningful information on metabolic rates. For example, oxygen consumption has been frequently used in comparative studies of epigean and hypogean organisms in relation to different environmental factors (e.g., Culver \& Poulson, 1971; Hervant et al., 1995, 1996, 1997a,b, 1998, 1999a; Issartel et al., 2005; Simčič et al., 2005, 2010; Mezek et al., 2010), while measurement of respiratory electron transport system (ETS) activity has been used sporadically (Simčič et al., 2005, 2010; Mezek et al., 2010; Simčič \& Sket, 2019). However, measurements of oxygen consumption can provide information about metabolic intensity under particular conditions, but the question remains as to what the measured energy demands mean, with regard to the whole metabolic capacity, for a single species. Therefore, ETS activity has been measured to estimate potential metabolic activity, i.e., the value of oxygen consumption that would occur if all enzymes functioned maximally (Muskó et al., 1995). Moreover, the ratio between oxygen consumption and potential metabolic activity (R/ETS ratio) has been frequently used as an estimator of the exploitation of metabolic potential for current metabolic activity in relation to various environmental conditions and reflects the plasticity and fitness of organisms (e.g., Muskó et al., 1995; Fanslow et al., 2001; Simčič et al., 2005; Lukančič et al., 2010; Simčič et al., 2015).

The goals of the present study were to: (i) investigate the effects of hypoxia exposure and increased 
temperature on respiratory response during posthypoxic recovery in closely related epigean and hypogean species; (ii) estimate the exploitation of metabolic potential for current metabolic demands during reoxygenation; (iii) explore the activity of the antioxidant enzymes displayed by the epigean and hypogean crustaceans during reoxygenation after exposure to severe hypoxia at different temperatures. To reach these goals, we measured oxygen consumption in normoxia and during normoxic recovery after exposure to severe hypoxia in closely related subterranean amphipod $N$. stygius and epigean amphipod $N$. zagrebensis at 10 and $20^{\circ} \mathrm{C}$. Moreover, ETS activity was determined to estimate the ratio between oxygen consumption and potential metabolic activity (R/ETS ratio). The activity of two antioxidant enzymes, i.e., catalase (CAT) and glutathione reductase (GR) was measured in both Niphargus species.

\section{MATERIALS AND METHODS}

\section{Collection and maintenance of animals}

Niphargus zagrebensis S. Karaman 1950 (syn. N. valachicus $z$., N.elegans $z$.) is eyeless and only feebly pigmented semisubterranean species that occurs in epigean waters where it is mixed with strongly pigmented epigean species (Karaman, 2019). Our sample was collected in stagnant or slowly flowing water in puddles and ditches with loamy bottoms and rich deposits of fallen leaves in a lowland oak forest Krakovski gozd at Kostanjevica (mean body mass \pm SE: $26.4 \pm 3.1 \mathrm{mg}$ wet mass, $\mathrm{n}=20$ ). As access to caves or interstitial water is here mainly absent, $N$. zagrebensis is considered as an epigean species in the present study.

Niphargus stygius (Schioedte 1847) is strongly stygobiotic species. The sample in this study was taken from the cave Unška koliševka at Planina (NE of Postojna, Slovenia) (30.1 $\pm 2.6 \mathrm{mg}, \mathrm{n}=20$ ). The habitats were small puddles of percolated water in artificially reshaped karst caves (past military galleries). Specimens of both species used in the study were males of a similar body mass $(t=1.12$, d.f. $=38$, $\mathrm{p}>0.05$ ). The mean yearly temperature (i.e., also the permanent temperature of ground waters) in 20052014 was $10-12^{\circ} \mathrm{C}$ at Novo mesto (close to Krakovski gozd) and $9-11^{\circ} \mathrm{C}$ at Postojna. The mean monthly temperatures in January and July varied from -1.7 to $1.4^{\circ} \mathrm{C}$ and 20.5 to $22.8^{\circ} \mathrm{C}$ in Novo mesto, but from -2.3 to $4.7^{\circ} \mathrm{C}$ and 18.5 to $22.3^{\circ} \mathrm{C}$ in Postojna (Statistical office, 2018).

Specimens were collected using a hand net. They were stored in plastic bottles and transported to the laboratory, where they were kept in aquaria in constant darkness at $10^{\circ} \mathrm{C}\left( \pm 0.5^{\circ} \mathrm{C}\right)$ in a thermoregulated chamber for three weeks. Aquaria were previously filled with chemically controlled (synthetic) and aerated water that was prepared by adding 2940 $\mathrm{mg} \mathrm{CaCl} \times 2 \mathrm{H}_{2} \mathrm{O}, 1230 \mathrm{mg} \mathrm{MgSO}_{4} \times 7 \mathrm{H}_{2} \mathrm{O}, 650 \mathrm{mg}$ $\mathrm{NaHCO}_{3}$ and $60 \mathrm{mg} \mathrm{KCl}$ into $10 \mathrm{~L}$ of bi-distilled water (ISO standard 6341, 1996). During this period of acclimation to laboratory conditions, animals were fed ad libitum with a commercial food (Sera crabs natural $\left.{ }^{\mathrm{TM}}\right)$. Water in aquaria was changed twice a week.

After acclimation to laboratory conditions, individuals of each species were transferred into two aquaria containing synthetic water and food. One aquarium with experimental animals was kept at $10^{\circ} \mathrm{C}$, while the water temperature in second one was gradually (i.e., $1^{\circ} \mathrm{C} / 12 \mathrm{~h}$ ) increased to $20^{\circ} \mathrm{C}$. After 5 days of acclimation to the newly reached temperature, animals were separately transferred from aquaria into $100 \mathrm{~mL}$ beaker containing $50 \mathrm{~mL}$ of synthetic water of adequate temperature, i.e., 10 or $20^{\circ} \mathrm{C}$. Animals were starved for 24 hours before oxygen consumption measurements were taken.

\section{Oxygen consumption measurement in normoxia and during post-hypoxic recovery}

Oxygen consumption was estimated by the closed bottle method (Lampert, 1984). First, ground-glass stoppered bottles were filled with synthetic and aerated water from the same, well-mixed, container to measure oxygen consumption in normoxia. The experimental bottles $(n=5)$ received animals, while two bottles served as controls. All bottles were stoppered and kept in the dark at 10 or $20^{\circ} \mathrm{C}$. The concentration of dissolved oxygen in the experimental and control bottles was measured with a 4-Channel fiber optic oxygen meter (PreSens OXY-4, Germany) for the first time after $30 \mathrm{~min}$, and a second time at the end of the incubation period (i.e., after $3 \mathrm{~h}$ ). Oxygen consumption was expressed as $\mathrm{mg} \mathrm{O}_{2}$ per $\mathrm{g}$ of wet weight $\left(\mathrm{mg} \mathrm{O}_{2}\right.$ $\mathrm{g}^{-1} \mathrm{WW} \mathrm{h} \mathrm{h}^{-1}$. After normoxia measurements, the same animals were introduced into experimental bottles filled with deoxygenated water that was generated by bubbling pure nitrogen gas. Water replacement was carried out according to a procedure that ensured minimal stress for the animals. First, single animal was gently sucked into a wide glass dropper along with a minimal volume of water, from where it was slowly released into a bottle filled with deoxygenated water. All bottles were stoppered and kept in the dark at 10 or $20^{\circ} \mathrm{C}$. The concentration of dissolved oxygen in bottles was below $0.3 \mathrm{mg} \mathrm{L}^{-1}$ during hypoxia. The selected incubation time for the exposure to hypoxia was longer than that for normoxia measurement in order to perceive the consequences of hypoxia in $N$. stygius, but also it was short enough to ensure the survival of all specimens of $N$. zagrebensis. After $5 \mathrm{~h}$ of incubation, the deoxygenated water in the bottles was quickly replaced with air saturated water. Animals were transferred in a small volume of water using a wide glass dropper, as described above. Oxygen concentration was measured during post-hypoxic recovery after $15 \mathrm{~min}, 30 \mathrm{~min}, 1,1.5,2,3,4,5,6,7$, and $8 \mathrm{~h}$ at 10 and $20^{\circ} \mathrm{C}$.

After oxygen consumption measurements, animals were placed between two sheets of filter paper and gently squeezed to remove the water from their surface. They were then placed on a preweighed piece of aluminium foil and weighed on an electrobalance (Sartorius BP $210 \mathrm{~S}$ ) with $0.1 \mathrm{mg}$ accuracy. 


\section{Procedure before measurements of ETS, CAT and GR activities}

Animals ( $\mathrm{n}=5$ ) were incubated in deoxygenated water (oxygen concentration was below $0.3 \mathrm{mg} \mathrm{L}^{-1}$ ) for $5 \mathrm{~h}$ at 10 or $20^{\circ} \mathrm{C}$. At the end of incubation in hypoxic conditions, the deoxygenated water was replaced with aerated water according the procedure described above in "Oxygen consumption measurement in normoxia and during post-hypoxic recovery" subsection. After $1 \mathrm{~h}$ of post-hypoxic recovery, individuals were immediately frozen in liquid nitrogen and stored at $-80^{\circ} \mathrm{C}$, prior to the preparation of the homogenate for the measurements of ETS, CAT and GR activities and determination of protein concentration. For controls, the individuals of each species $(n=5)$ were kept in normoxic conditions at each experimental temperature and were frozen and stored as described above.

\section{ETS activity}

Respiratory electron transport system (ETS) activity was measured using the method originally proposed by Packard (1971) and improved by G.-Tóth (1999). The ETS activity of each animal was determined using the procedure described in Simčič \& Sket (2019). The rate of tetrazolium dye reduction to formazan was converted to equivalent oxygen as described by Kenner \& Ahmed (1975).

\section{Catalase (CAT) activity}

CAT activity was measured according to the method proposed by Aebi (1984). The procedure used in the present study was previously described in detail in Simčič et al. (2015). Enzyme activities were expressed as enzyme units (U), where one $U$ was defined as the amount of CAT that degrades one $\mu$ mol of hydrogen peroxide in $1 \mathrm{~min}$. These results were divided by the total amount of protein to give the specific CAT activity per mg protein.

\section{Glutathione reductase (GR) activity}

GR activity was determined according to the method proposed by Carlberg \& Mannervik (1985), using the procedure described in Simčič et al. (2015). One U was defined as the amount of GR that degrades $1 \mu \mathrm{mol}$ of NADPH in $1 \mathrm{~min}$. The specific GR activity per $\mathrm{mg}$ protein was calculated.

\section{Protein concentration}

Protein concentration was determined using a commercial Pierce ${ }^{\mathrm{TM}}$ BCA protein assay kit (Thermo Scientific, USA) according to the manufacturer's recommendations. Absorbance of the samples was measured using a Lambda UV/Vis spectrophotometer (PerkinElmer, USA).

\section{Data analysis}

Values are presented as means $\pm \mathrm{SE}$. The data were first tested for normality of distributions (Shapiro-Wilk test) and homogeneity of variances (Levene's test), and $\log$ transformed when necessary. Body masses of the two species were compared by Student's t-test. The differences between values were investigated using one-way ANOVAs. When significant differences in ANOVAs were found, the post hoc Tukey's test was performed to find out which means differ significantly. All statistical analyses were conducted with SPSS 20.0 (SPSS Inc. Chicago, Illinois, USA).

\section{RESULTS}

\section{Oxygen consumption in normoxia and during post-hypoxic recovery}

Oxygen consumption during reoxygenation varied significantly - from $1.16 \mathrm{mg} \mathrm{O}_{2} \mathrm{~g}^{-1} \mathrm{~h}^{-1}$ to $0.12 \mathrm{mg} \mathrm{O}_{2} \mathrm{~g}^{-1}$ $\mathrm{h}^{-1}$ in $N$. zagrebensis (ANOVA, $\mathrm{F}_{10,44}=8.61 ; \mathrm{p}<0.001$ ), and from $0.38 \mathrm{mg} \mathrm{O}_{2} \mathrm{~g}^{-1} \mathrm{~h}^{-1}$ to $0.06 \mathrm{mg} \mathrm{O}_{2} \mathrm{~g}^{-1} \mathrm{~h}^{-1}$ in $N$. stygius (ANOVA, $\mathrm{F}_{10,44}=5.46 ; \mathrm{p}<0.001$ ) at $10^{\circ} \mathrm{C}$ (Fig. 1a). Similarly, both species had significantly increased oxygen consumption after a half an hour in normoxic recovery period at $10^{\circ} \mathrm{C}$ when compared to oxygen consumption in normoxia (Control), but with different increases. Oxygen consumption was, compared to the control, nearly 5-times (4.9) higher in hypogean $N$. stygius, and almost 10-times (9.7) higher in epigean $N$. zagrebensis. After reaching the maximal value, oxygen consumption of both species during normoxic recovery period was decreasing for several hours, until it was similar to the control value (after $2 \mathrm{~h}$ of normoxic recovery in $N$. stygius and $5 \mathrm{~h}$ in $N$. zagrebensis).

Significant variations in oxygen consumption during reoxygenation were also observed in $N$. zagrebensis (ANOVA, $\left.\quad \mathrm{F}_{10,44}=7.36 ; \mathrm{p}<0.001\right)$ and $N$. stygius (ANOVA, $\left.\mathrm{F}_{10,44}=15.70 ; \mathrm{p}<0.001\right)$ at $20^{\circ} \mathrm{C}$, where values ranged from $1.30 \mathrm{mg} \mathrm{O}_{2} \mathrm{~g}^{-1} \mathrm{~h}^{-1}$ to $0.34 \mathrm{mg} \mathrm{O}_{2}$ $\mathrm{g}^{-1} \mathrm{~h}^{-1}$ and from $0.76 \mathrm{mg} \mathrm{O}_{2} \mathrm{~g}^{-1} \mathrm{~h}^{-1}$ to $0.13 \mathrm{mg} \mathrm{O}_{2} \mathrm{~g}^{-1} \mathrm{~h}^{-1}$,
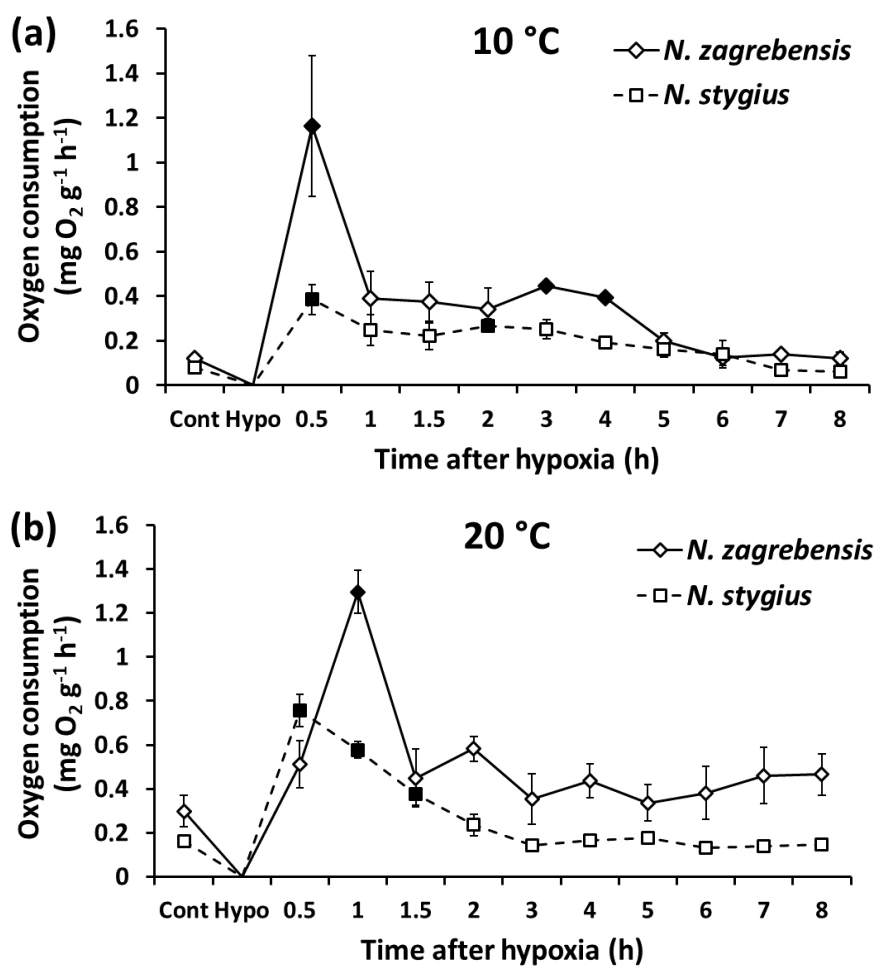

Fig. 1. Oxygen consumption in normoxia (Cont) and during subsequent normoxic recovery after severe hypoxia ( $\left.<0.3 \mathrm{mg} \mathrm{O}_{2} \mathrm{~L}^{-1} ; \mathrm{Hypo}\right)$ measured in epigean Niphargus zagrebensis and in hypogean Niphargus stygius in darkness at $10^{\circ} \mathrm{C}(\mathbf{a})$ and $20^{\circ} \mathrm{C}(\mathbf{b})$. Values are means $\pm S E$ for $n=5$. Full symbols differ significantly from control (Cont) $-p<0.05$ (ANOVA, Tukey's HSD test). 
respectively (Fig. 1b). Different patterns of subsequent normoxic recovery after severe hypoxia were observed at $20^{\circ} \mathrm{C}$ than at $10^{\circ} \mathrm{C}$ for $N$. zagrebensis. $N$. stygius had, similarly, the highest oxygen consumption at $0.5 \mathrm{~h}$ of recovery period, but $N$. zagrebensis reached the highest oxygen consumption after $1 \mathrm{~h}$ of recovery. Oxygen consumption rate increased for 4.6-times in hypogean $N$. stygius $(0.5 \mathrm{~h})$ and 4.4-times in epigean $N$. zagrebensis $(1 \mathrm{~h})$. After reaching maximal value, oxygen consumption of $N$. stygius decreased gradually for several hours, but for $N$. zagrebensis a steep decrease in oxygen consumption was observed.

\section{ETS activity}

Significant differences in ETS activity between temperatures and oxygen conditions (i.e., in normoxia as control and $1 \mathrm{~h}$ after post-hypoxic recovery in normoxia) were observed for $N$. zagrebensis $\left(\mathrm{F}_{3,16}=23.83, \mathrm{p}<0.001\right.$, Fig. $\left.2 \mathrm{a}\right)$ and $N$. stygius $\left(\mathrm{F}_{3,16}=195.16, \mathrm{p}<0.001\right.$, Fig. 2b). Tukey post hoc test showed that ETS activity of $N$. zagrebensis was similar in normoxia and during post-hypoxic recovery within each temperature, but it differed significantly between temperatures, where it was higher at $20^{\circ} \mathrm{C}$. In $N$. stygius, significant differences were observed between temperatures and oxygen treatments. Higher ETS activities were obtained at higher temperature and during post-hypoxic recovery, respectively.


Fig. 2. Respiratory electron transport system (ETS) activity in normoxia (Control) and after $1 \mathrm{~h}$ of subsequent normoxic recovery from severe hypoxia $\left(<0.3 \mathrm{mg} \mathrm{O}_{2} \mathrm{~L}^{-1}\right)$ determined in epigean Niphargus zagrebensis (a) and hypogean Niphargus stygius (b) at $10^{\circ} \mathrm{C}$ and $20^{\circ} \mathrm{C}$. Bars labelled with different letters differ significantly $-p<0.05$ (ANOVA, Tukey's HSD test). Values are means $\pm S E$ for $n=5$.

\section{R/ETS ratio}

The R/ETS ratio was calculated to illustrate the exploitation of metabolic potential for actual metabolic activity. $N$. stygius and $N$. zagrebensis had similar R/ETS ratios at $10^{\circ} \mathrm{C}(12$ and $13 \%$, respectively) and at $20^{\circ} \mathrm{C}(8 \%)$ in normoxia (Control) before exposure to hypoxic stress (Fig. 3). During post-hypoxic recovery at $10^{\circ} \mathrm{C}$, the R/ETS ratio of $N$. zagrebensis showed an extreme increase in oxygen consumption and exploitation of metabolic potential for current metabolic activity at $0.5 \mathrm{~h}$ of normoxic recovery (i.e., $115 \%$ ), whereas that of $N$. stygius increased just up to $40 \%$. At $20^{\circ} \mathrm{C}$, maximal value of R/ETS ratio was $30 \%$ for $N$. stygius and $47 \%$ for N. zagrebensis.


Fig. 3. Estimation of the exploitation of electron transport system (ETS) activity (metabolic potential) for actual metabolic activity (R/ ETS ratio, in percentages) in Niphargus zagrebensis and $N$. stygius at $10^{\circ} \mathrm{C}$ (a) and $20^{\circ} \mathrm{C}(\mathbf{b})$ in normoxia (Cont) and during normoxic recovery after severe hypoxia. Mean values of oxygen consumption rates and ETS activities were used for the calculation of ratios.

\section{Response of antioxidant enzymes}

Hypoxic stress, followed by $1 \mathrm{~h}$ of post-hypoxic recovery in normoxia and increased temperature, showed significant modification in CAT activity $\left(\mathrm{F}_{3,16}=40.84, \mathrm{p}<0.001\right.$, Fig. 4) and GR activity $\left(\mathrm{F}_{3,16}=14.33, \mathrm{p}<0.001\right.$, Fig. 5) for $N$. stygius, where higher activities of CAT and GR were measured in animals during post-hypoxic recovery in normoxia compared to control animals at $20^{\circ} \mathrm{C}$. Similarly, $N$. zagrebensis showed significant variation in CAT activity $\left(\mathrm{F}_{3,16}=3.84, \mathrm{p}<0.05\right)$ and GR activity $\left(\mathrm{F}_{3,16}=3.62\right.$, $\mathrm{p}<0.05)$. Tukey post hoc test showed that $N$. zagrebensis had significantly higher CAT activity during normoxic recovery after severe hypoxia at $20^{\circ} \mathrm{C}$ than at $10^{\circ} \mathrm{C}$. Moreover, GR activity of $N$. zagrebensis was higher during subsequent post-hypoxic recovery compared to the control at $20^{\circ} \mathrm{C}$. 

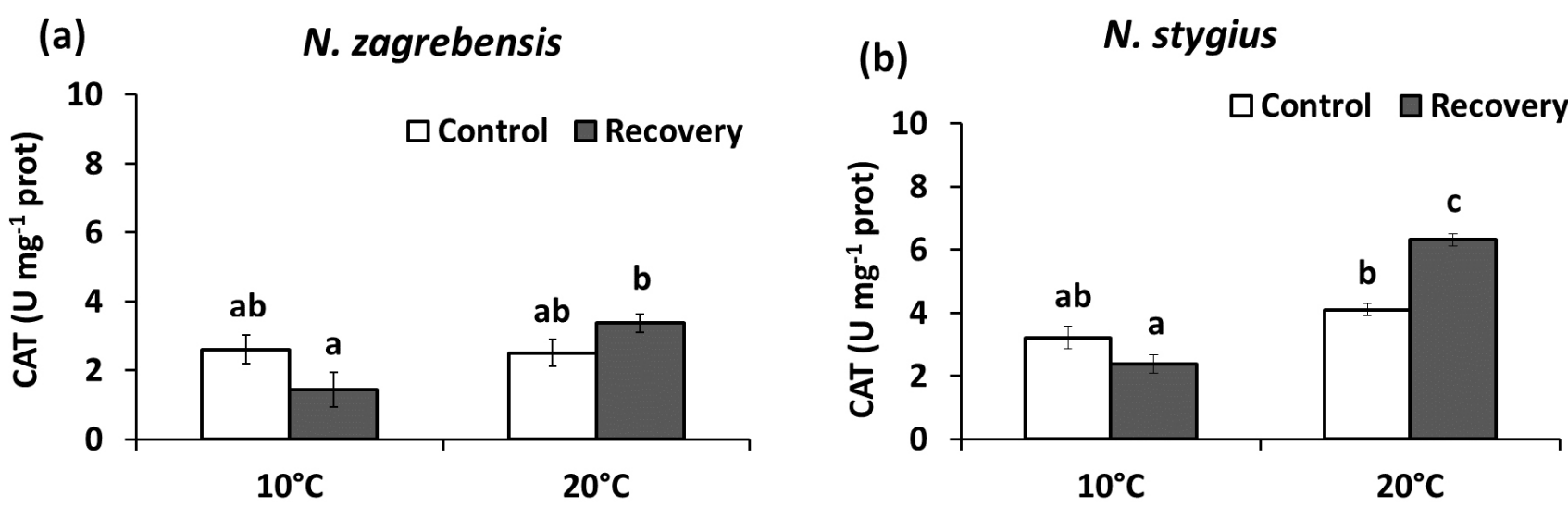

Fig. 4. Catalase (CAT) activity measured in Niphargus zagrebensis (a) and $N$. stygius (b) at 10 and $20^{\circ} \mathrm{C}$ in normoxia (Control) and after $1 \mathrm{~h}$ of normoxic recovery from severe hypoxia $\left(<0.3 \mathrm{mg} \mathrm{O}_{2} \mathrm{~L}^{-1}\right)$. Bars labelled with different letters differ significantly $-p<0.05$ (ANOVA, Tukey's HSD test). Values are means \pm SE for $n=5$.

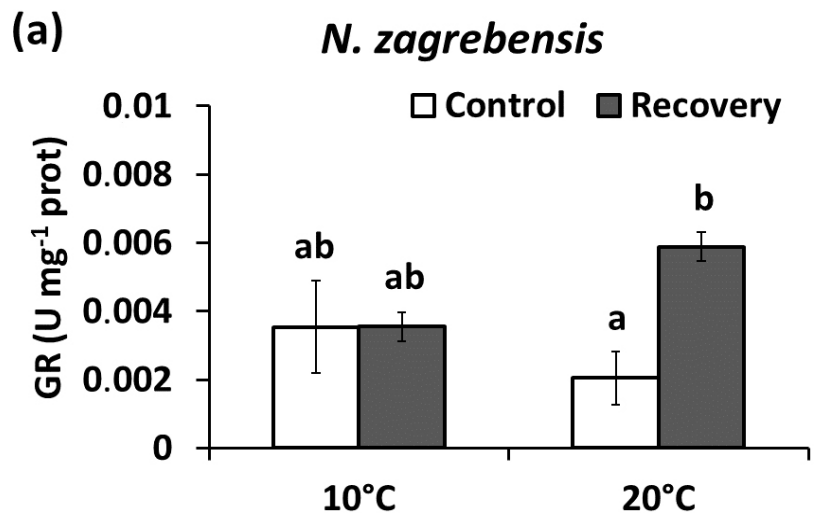

(b) N. stygius

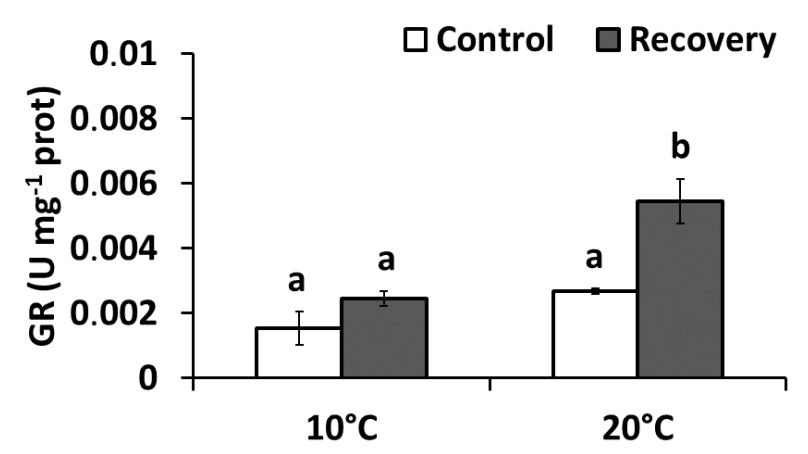

Fig. 5. Glutathion reductase (GR) activity measured in Niphargus zagrebensis (a) and N. stygius (b) at 10 and $20^{\circ} \mathrm{C}$ in normoxia (Control) and after $1 \mathrm{~h}$ of normoxic recovery from severe hypoxia $\left(<0.3 \mathrm{mg} \mathrm{O}_{2} \mathrm{~L}^{-1}\right)$. Bars labelled with different letters differ significantly $-p<0.05$ (ANOVA, Tukey's HSD test). Values are means \pm SE for $n=5$.

\section{DISCUSSION}

While oxygen level and temperature have been proven as interlinked stressors in aquatic organisms (Pörtner \& Knust, 2007; Pörtner, 2010) and, moreover, they both have significant effects on oxygen consumption and ROS formation, the interaction of both factors expectedly resulted in different respiratory and antioxidant responses to hypoxia-reoxygenation and increased temperature in epigean and hypogean Niphargus species, namely $N$. zagrebensis and $N$. stygius. For both species, post-hypoxic recovery resulted in increased oxygen consumption. The higher increase of oxygen consumption in epigean than hypogean species is in accord with the findings of previous studies, where distantly related epigean and hypogean species were compared (Hervant et al., 1995, 1996, 1998). For example, Hervant et al. (1998) reported that the main explanation for the lower oxygen debt shown by hypogean organisms is the lower energetic expenditures noticed during hypoxia, partly due to a decrease in locomotory and ventilatory activities. Moreover, oxygen consumption of $N$. stygius increased similarly during recovery at 10 and $20^{\circ} \mathrm{C}$, i.e., approximately for five-times of normoxic rates, but $N$. zagrebensis increased its oxygen consumption relatively less at $20^{\circ} \mathrm{C}$ than at $10^{\circ} \mathrm{C}$. However, it is ecologically very important for organisms to recover quickly and completely from hypoxic or anoxic stress when oxygen is once more available (Hervant \& Malard,
2019). Previous studies revealed faster replenishment of ATP levels in hypogean than in epigean species during post-hypoxic recovery (Hervant et al., 1995, 1996, 1997b).

Moreover, observations of the hypogean Stenasellus virei Dollfus, Niphargus virei Chevreux, $N$. rhenorhodanensis and the epigean Asellus aquaticus Linne and Gammarus fossarum Koch showed that part of the end products was excreted and part was metabolized (Hervant et al., 1995, 1996, 1997b, 1999b). Excretion is an important mechanism for the disposal of lactate during aerobic recovery in epigean species. This is a costly strategy because of a loss of energy-rich carbon chains. In contrast, hypogean crustaceans preferentially use glyconeogenesis to convert lactate into glycogen stores (Hervant \& Malard, 2019). Thus, the gradual decrease of oxygen consumption in $N$. stygius after reaching its maximal value during normoxic recovery could indicate a subsequent turnover of the anaerobic end products. But in $N$. zagrebensis, the maximal oxygen consumption observed after 0.5 and $1 \mathrm{~h}$ of post-hypoxic recovery period at $10^{\circ} \mathrm{C}$ and $20^{\circ} \mathrm{C}$, respectively, is followed by a rapid decrease at both temperatures. Therefore, it is assumed that the reason for the quick decrease in oxygen consumption and relatively low oxygen consumption in $N$. zagrebensis at higher temperatures is likely the excretion of anaerobic end products instead of being converted, as evidenced by epigean species in 
previous studies (Hervant et al., 1995, 1996, 1997b, 1999b).

As expected, higher ETS activities were obtained at a higher temperature in both species, while differences between species were observed in response to hypoxic stress, where $N$. stygius had higher ETS activity after exposure to hypoxic stress compared to controls, but $N$. zagrebensis did not. Le Moullac et al. (2007) reported that 20 days of hypoxia significantly increased the activity of ETS in the oyster Crassostrea gigas (Thunberg). The authors assumed that the stimulation of the ETS activity, observed in molluscs, was linked to the up-regulation of some genes of the respiratory chain, as was previously observed in anoxia tolerant vertebrates (Krivoruchko \& Storey, 2015). Many species have developed mechanisms that allow them to compensate for periods of low oxygen. These mechanisms improve oxygen delivery to tissues and/ or to increase ATP production by oxygen-independent means (e.g., glycolysis) to compensate for the reduced ATP output by oxygen-dependent pathways in the mitochondria (Krivoruchko \& Storey, 2015). Hervant et al. (1999b) reported that the metabolic response of $N$. virei during post-hypoxic recovery mainly exhibited the characteristics of vertebrates, where a strategy of lactate removal was quite different from that observed in epigean crustaceans, favouring lactate supported gluco-and glyconeogenesis and rapid glycogen replenishment instead of rapid lactate removal via oxidative pathways. Thus, it seems that hypoxic tolerant $N$. stygius exhibited stimulation of ETS activity during hypoxic stress in order to provide sufficient ATP production, while $N$. zagrebensis was incapable of increasing its metabolic potential.

The ratio between oxygen consumption and ETS activity (R/ETS) is an important index of organisms' metabolism (Muskó et al., 1995; Fanslow et al., 2001; Simčič et al., 2005; Lukančič et al., 2010; Simčič et al., 2015; Simčič \& Sket, 2019). The values of the present study, measured in normoxic conditions before exposure to severe hypoxia, are in agreement with those of Simčič et al. (2005) reported for hypogean Niphargus species, where exploitation of metabolic potential ranged from 12 to $20 \%$ in N. krameri and two populations of $N$. stygius. It seems that closely related epigean and hypogean Niphargus species in normoxia possess a similar ratio, while a distantly related epigean species, namely Gammarus fossarum, used a higher percentage (i.e., 40\%) of metabolic potential for actual metabolic activity (Simčič et al., 2005). Lower exploitation of metabolic potential is an advantage in variable environments, where organisms could immediately use the existing enzyme machinery for increased metabolic activity during recovery under favourable conditions (Fanslow et al., 2001; Simčič et al., 2005; Žagar et al., 2015). Moreover, the relatively low ratio (i.e., 9\%) of Nereis virens was explained by its low activity and intermittent exposure to anoxic conditions (Cammen et al., 1990). Stimulated ETS activity under severe hypoxia in $N$. stygius, observed in the present study, probably additionally supported quick and efficient post-hypoxic recovery. Thus, the exploitation of metabolic potential in $N$. stygius, which increased up to $40 \%$ at $10^{\circ} \mathrm{C}$, was a metabolically more favourable condition than the high $\mathrm{R} / \mathrm{ETS}$ ratio in $N$. zagrebensis at $10^{\circ} \mathrm{C}$ which indicated exploitation of the whole metabolic potential. A similar pattern with higher exploitation of metabolic potential in $N$. zagrebensis than $N$. stygius was also observed at $20^{\circ} \mathrm{C}$. Lower exploitation of metabolic potential at $20^{\circ} \mathrm{C}$ than at $10^{\circ} \mathrm{C}$ is in accord with the results of the previous studies, where R/ETS ratio decreased with increasing temperature due to different response of oxygen consumption and ETS activity to temperature change (Bamstedt, 1980; Muskó et al., 1995; Simčič \& Brancelj, 1997; Simčič, 2005; Simčič \& Sket, 2019). Furthermore, relatively lower R/ETS ratios in $N$. stygius exhibited at the end of the recovery period than they were displayed in normoxia before exposure to hypoxia (Control) indicated on lower energetic expenditures.

During hypoxia and subsequent reoxygenation increased ROS levels are expected to activate antioxidant defenses (Hermes-Lima et al., 2015). The results of the present study showed a higher activity of antioxidant enzyme CAT in $N$. stygius during posthypoxic recovery than it was in control at $20^{\circ} \mathrm{C}$. These results are in accord with the findings of the previous studies on crustaceans where increased CAT activities in hypoxia and reoxygenation were reported (Gorokhova et al., 2010, 2013; Trasviña-Arenas et al., 2013). Moreover, increased GR activity that catalyzes the reduction of GSSG to GSH was observed in both Niphargus species during post-hypoxic recovery at $20^{\circ} \mathrm{C}$. Nevertheless, hypogean $N$. stygius had, under hypoxia and subsequent reoxygenation, increased activity of the primary antioxidant enzyme, i.e., CAT, while epigean $N$. zagrebensis did not. Lawniczak et al. (2013) similarly reported the increased GPx activity in subterranean amphipod $N$. rhenorhodanensis after $24 \mathrm{~h}$ exposure to anoxia. If the antioxidant potential is high enough, ROS level returns to the initial level before oxidative stress could occur. However, when the efficiency of the antioxidant system does not counterbalance enhanced ROS production, the presence of excess ROS in cells causes oxidative damage of lipids, proteins, and nucleic acids (Lushchak et al., 2001). Thus, lower CAT activity in $N$. zagrebensis than $N$. stygius at $20^{\circ} \mathrm{C}$ indicates a lower response to hypoxia in former species. Consequently, it is assumed that a decline in ETS activity of $N$. zagrebensis at $20^{\circ} \mathrm{C}$ could be caused by a less efficient antioxidant defense that resulted in the oxidative damages of cellular structures. However, to test this assumption, some parameters of oxidative damage, e.g., lipid peroxidation or protein carbonylation, ought to be measured.

In this study, we observed higher activities of CAT and GR during post-hypoxic recovery in comparison to controls at $20^{\circ} \mathrm{C}$, but not at $10^{\circ} \mathrm{C}$. Bagnyukova et al. (2007) claimed that the activities of primary antioxidant enzymes - superoxide dismutase (SOD) and CAT - were unaffected in organs of goldfish Carassius auratus, whereas glutathione-dependent enzymes, such as also GR, were elevated after more prolonged exposure to high temperature. In the 
present study, the exposure of organisms of both Niphargus species solely to higher temperatures did not increase CAT nor GR activities, whereas combined effects of high temperature and hypoxia with subsequent normoxic recovery resulted in increased CAT and GR activities of both species. As reported by Vinagre et al. (2012), an oxidative stress response is not directly correlated to temperature. It is lowest at the optimal temperature, and it increases outside this species' upper and lower optimum thermal limits. In addition, as $10^{\circ} \mathrm{C}$ is an average habitat temperature of both species and a permanent one for $N$. stygius, a higher temperature (i.e., $20^{\circ} \mathrm{C}$ ) likely contributes to overall environmental stress. This explanation is in agreement with the reports of Gorokhova et al. (2013), who found that co-exposure of amphipod Monoporeia affinis (Lindstrom) to both fluctuating hypoxia and contaminants caused greater increase in antioxidants and lipid peroxidation, and slowed recovery from hypoxia as indicated by CAT and glutathione redox state (GSH/GSSG ratio). We, therefore, assumed that temperature-stable subterranean habitats represent an advantage for hypogean animals that have to face frequent exposure to variable oxygen concentrations.

In conclusion, closely related epigean and hypogean Niphargus species have, in fact, similar oxygen consumption in normoxia, but they respond differently to exposure to environmental stressors, such as severe hypoxia and increased temperature. Thus, as reported previously by Hervant et al. (1998), the lower energetic expenditures noticed during hypoxia due to a decrease in locomotory and ventilatory activities contributed to lower oxygen debt in hypogean species. Moreover, the consistent respiratory response of $N$. stygius to hypoxia at 10 and $20^{\circ} \mathrm{C}$, i.e., gradual decreasing of oxygen consumption during repayment of oxygen debt as a result of metabolization of anaerobic end products, and enhanced antioxidant enzyme activities after exposure to severe hypoxia and higher temperature, are probably related to some physiological and biochemical traits of stygobitic species that enable $N$. stygius to cope successfully with specific conditions in subterranean environments. However, a high resistance to hypoxia, followed by the activation of antioxidant defenses during reoxygenation, is not universally found in subterranean species (e.g., Issartel et al., 2009). Thus, additional studies on the mechanisms involved in hypoxia tolerance of different groundwater animals are needed to improve understanding of adaptation to restrict oxygen conditions.

\section{ACKNOWLEDGEMENTS}

The authors thank Jennifer C. Ellis for suggestions on an earlier draft of this manuscript and the English revision of the text and the reviewers for constructive comments. This study was financially supported by the Slovenian Research Agency (Research Program P1-0255).

Authorship statement: TS and BS designed and directed the study. BS collected and determined the animals. TS performed the measurements and analyzed the data. TS wrote the paper with substantial input from BS.

\section{REFERENCES}

Aebi, H., 1984. Catalase in vitro. Methods in Enzymology 105, 121-126.

https://doi.org/10.1016/S0076-6879(84)05016-3

Bagnyukova, T.V., Lushchak, O.V., Storey, K.B., Lushchak, V.I., 2007. Oxidative stress and antioxidant defense responses by goldfish tissues to acute change of temperature from 3 to $23^{\circ} \mathrm{C}$. Journal of Thermal Biology, 32, 227-234.

https://doi.org/10.1016/j.jtherbio.2007.01.004

Bamstedt, U., 1980. ETS activity as an estimator of respiratory rate of zooplankton populations. The significance of variations in environmental factors. Journal of Experimental Marine Biology and Ecology, 42, 267-283.

https://doi.org/10.1016/0022-0981(80)90181-1

Biswas, J., 1991. Metabolic efficiency and regulation of body weight: a comparison between life in hypogean and epigean ecosystems. International Journal of Speleology, 20, 15-22

https://doi.org/10.5038/1827-806X.20.1.2

Cammen, L.M., Corwin, S., Christensen, J.P., 1990. Electron transport system (ETS) activity as a measure of benthic macrofaunal metabolism. Marine Ecology Progress Series, 65, 171-182.

https://doi.org/10.3354/meps065171

Carlberg, C., Mannervik, B., 1985. Glutathione reductase. In: Meister, A. (Ed.). Methods in Enzymology, vol 113. Academic Press, New York, p. 488-495.

Couto N., Wood J., Barber, J., 2016. The role of glutathione reductase and related enzymes on cellular redox homoeostasis network. Free Radical Biology and Medicine, 95, 27-42.

https://doi.org/10.1016/j.freeradbiomed.2016.02.028

Culver, D.C., Poulson, T.L., 1971. Oxygen consumption and activity in closely related amphipod populations from cave and surface habitats. American Midland Naturalist, 85, 74-84. https://doi.org/10.2307/2423913

Ellington, W.R., 1983. The recovery from anaerobic metabolism in invertebrates. Journal of Experimental Zoology, 228, 431-444.

https://doi.org/10.1002/jez.1402280305

Fanslow, D.L., Nalepa, T.F., Johengen, T.H., 2001. Seasonal changes in the respiratory electron transport system (ETS) and respiration rate of the zebra mussel, Dreissena polymorpha in Saginaw Bay, Lake Huron. Hydrobiologia, 448, 61-70.

Gorokhova E., Löf, M., Halldórsson, H.P., Tjärnlund, U., Lindström, M., Elfwing, T., Sundelin, B., 2010. Single and combined effects of hypoxia and contaminated sediments on the amphipod Monoporeia affinis in laboratory toxicity bioassays based on multiple biomarkers. Aquatic Toxicology, 99, 263-274. https://doi.org/10.1016/j.aquatox.2010.05.005

Gorokhova, E., Löf, M., Reutgard, M., Lindström, M., Sundelin, B., 2013. Exposure to contaminants exacerbates oxidative stress in amphipod Monoporeia affinis subjected to fluctuating hypoxia. Aquatic Toxicology, 127, 46-53. https://doi.org/10.1016/j.aquatox.2012.01.022

G.-Tóth, L., 1999. Aktivität des Elektronentransportsystems. In: von Tümpling, W., Friedrich, G. (Eds.), Biologische Gewässeruntersuchung. Methoden der Biologischen Wasseruntersuchung 2, Gustav Fischer Verl., Jena, Stuttgart, Lübeck, Ulm, p. 465-473. 
Hermes-Lima, M., Moreira, D.C., Rivera-Ingraham, G.A., Giraud-Billoud, M., Genaro-Mattos, T.C., Campos, É.G., 2015. Preparation for oxidative stress under hypoxia and metabolic depression: Revisiting the proposal two decades later. Free Radical Biology and Medicine, 89, 1122-1143.

https://doi.org/10.1016/j.freeradbiomed.2015.07.156

Herreid, C., 1980. Hypoxia in invertebrates. Comparative Biochemistry \& Physiology A, 67, 311-320. https://doi.org/10.1016/S0300-9629(80)80002-8

Hervant, F., Mathieu, J., Garin, D., Freminet, A., 1995. Behavioral, ventilatory, and metabolic responses to severe hypoxia and subsequent recovery of the hypogean Niphargus rhenorhodanensis and the epigean Gammarus fossarum (Crustacea: Amphipoda). Physiological Zoology, 68, 223-244.

https://doi.org/10.1086/physzool.68.2.30166501

Hervant, F., Mathieu, J., Garin, D., Freminet, A., 1996. Behavioral, ventilatory, and metabolic responses of hypogean amphipod Niphargus virei and the epigean isopod Asellus aquaticus to severe hypoxia and subsequent recovery. Physiological Zoology, 69, 12771300.

https://doi.org/10.1086/physzool.69.6.30164261

Hervant, F., Mathieu, J., Barré, H., Simon, K., Pinon, C., 1997a. Comparative study on the behavioural, ventilatory, and respiratory responses of hypogean and epigean crustaceans to long-term starvation and subsequent feeding. Comparative Biochemistry \& Physiology A, 118, 1277-1283. https://doi.org/10.1016/S0300-9629(97)00047-9

Hervant, F., Mathieu, J., Messana, G., 1997b. Locomotory, ventilatory and metabolic responses of the subterranean Stenasellus virei (Crustacea, Isopoda) to severe hypoxia and subsequent recovery. Comptes rendus de l'Académie des SciencesParis, Sciences de la vie / Life Sciences, 320, 139-148.

https://doi.org/10.1016/S0764-4469(97)85005-6

Hervant, F., Mathieu, J., Messana, G., 1998. Oxygen consumption and ventilation in declining oxygen tension and post-hypoxic recovery in epigean and hypogean crustaceans. Journal of Crustacean Biology, 18, 717-727.

https://doi.org/10.1163/193724098X00593

Hervant, F., Mathieu, J., Culver, D.C., 1999a. Comparative responses to severe hypoxia and subsequent recovery in closely related amphipod populations (Gammarus minus) from cave and surface habitats. Hydrobiologia, 392, 197-204.

https://doi.org/10.1023/A:1003511416509

Hervant, F., Garin D., Mathieu, J., Freminet, A., 1999b. Lactate metabolism and glucose turnover in the subterranean crustacean Niphargus virei during posthypoxic recovery. Journal of Experimental Biology, 202, 579-592.

https://jeb.biologists.org/content/202/5/579.articleinfo

Hervant, F., Malard, F., 2019. Adaptations: Low oxygen. In: White, W.B., Culver, D.C, Pipan, T. (Ed.), Encyclopedia of caves ( $3^{\text {rd }}$ Ed.). Elsevier/Academic Press, London, p. 8-15.

https://doi.org/10.1016/B978-0-12-814124-3.00002-9

Hochachka, P.W., Somero, G.N., 2002. Biochemical adaptation: Mechanism and process in physiological evolution. Oxford University Press, Oxford, 480 p.

Huey, R.B., Kingsolver, J.G., 1989. Evolution of thermal sensitivity of ectotherms. Trends in Ecology \& Evolution, 4, 131-135.

https://doi.org/10.1016/0169-5347(89)90211-5
ISO-standard 6341 (1996) Determination of the inhibition of the mobility of Daphnia magna Straus (Cladocera, Crustacea)-Acute toxicity test (3rd ed.). Geneva: International Organization for Standardization.

Issartel, J., Hervant, F., Voituron, Y., Renault, D., Vernon, $\mathrm{Ph} ., 2005$. Behavioural, ventilatory and respiratory responses of epigean and hypogean crustaceans to different temperatures. Comparative Biochemistry \& Physiology A, 141, 1-7.

https://doi.org/10.1016/j.cbpb.2005.02.013

Issartel, J., Hervant, F., de Fraipont, M., Clobert, J., Voituron, Y., 2009. High anoxia tolerance in the subterranean salamander Proteus anguinus without oxidative stress nor activation of antioxidant defenses during reoxygenation. Journal of Comparative Physiology B, 179, 543-551. https://doi.org/10.1007/s00360-008-0338-9

Karaman, G.S., 2019. The subterranean species Niphargus zagrebensis S. Kar. 1950 (Fam. Niphargidae) on Balkan (Contribution to the knowledge of the Amphipoda 312). Agriculture \& Forestry, 65, 67-89. https://doi.org/10.17707/AgricultForest.65.4.07

Kenner, R.A., Ahmed, S.I., 1975. Measurements of electron transport activities in marine phytoplankton. Marine Biology, 33, 119-127. https://doi.org/10.1007/BF00390716

Krivoruchko, A., Storey, K.B., 2015. Turtle anoxia tolerance: Biochemistry and gene regulation-Review. Biochimica et Biophysica Acta, 1850, 1188-1196. https://doi.org/10.1016/j.bbagen.2015.02.001

Lampert, W., 1984. The measurement of respiration. In: Downing, J.A., Rigler, F.H. (Eds.) A manual on methods for the assessment of secondary productivity in fresh water. IPB Handbook 17, Blackwell Scientific Publications, Oxford, p. 413-468.

Lawniczak, M., Romestaing, C., Roussel, D., Maazouzi, C., Renault, D., Hervant, F., 2013. Preventive antioxidant responses to extreme oxygen level fluctuation in a subterranean crustacean. Comparative Biochemistry \& Physiology A 165, 299-303.

https://doi.org/10.1016/j.cbpa.2013.03.028

Le Moullac, G., Quéau, I., Le Souchu, P., Pouvreau, S., Moal, J., Le Coz, J.R., Samain, J.F., 2007. Metabolic adjustments in the oyster Crassostrea gigas according to oxygen level and temperature. Marine Biology Research, 3, 357-366.

https://doi.org/10.1080/17451000701635128

Lukančič, S., Žibrat, U., Mezek, T., Jerebic, A., Simčič, T., Brancelj, A., 2010. A new method for early assessment of effects of exposing two non-target crustacean species, Asellus aquaticus and Gammarus fossarum, to pesticides, a laboratory study. Toxicology $\&$ Industrial Health, 26, 217-228.

https://doi.org/10.1177/0748233710362379

Lushchak, V.I., 2011. Environmentally induced oxidative stress in aquatic animals. Aquatic Toxicology, 101, 13-30.

https://doi.org/10.1016/j.aquatox.2010.10.006

Lushchak, V.I., Lushchak, L.P., Mota, A.A., HermesLima, M., 2001. Oxidative stress and antioxidant defenses in goldfish Carassius auratus during anoxia and reoxygenation. American Journal of PhysiologyRegulatory, Integrative and Comparative Physiology, 280, R100-R107. https://doi.org/10.1152/ajpregu.2001.280.1.R100

Lushchak, V.I., Bagnyukova, T.V., 2006. Effects of different environmental oxygen levels on free radical processes in fish. Comparative Biochemistry \& Physiology B, 144, 283-289.

https://doi.org/10.1016/j.cbpb.2006.02.014 
Malard, F., Hervant, F., 1999. Oxygen supply and the adaptations of animals in groundwater. Freshwater Biology, 41, 1-30. https://doi.org/10.1046/j.1365-2427.1999.00379.x

Mezek, T., Simčič, T., Arts, M.T., Brancelj A., 2010. Effect of fasting on hypogean (Niphargus stygius) and epigean (Gammarus fossarum) amphipods: a laboratory study. Aquatic Ecology, 44, 397-408. https://doi.org/10.1007/s10452-009-9299-7

Muskó, I.B., G.-Tóth, L, Szábo, E., 1995. Respiration and respiratory electron transport system (ETS) activity of two amphipods: Corophium curvispinum G. O. Sars and Gammarus fossarum Koch. Polish Archives of Hydrobiology, 42, 547-558.

Packard, T.T., 1971. The measurement of respiratory electron transport activity in marine phytoplankton. Journal of Marine Research, 29, 235-244.

Pörtner, H.-O., 2010. Oxygen- and capacity-limitation of thermal tolerance: a matrix for integrating climaterelated stressor effects in marine ecosystems. Journal of Experimental Biology, 213, 881-893.

https://doi.org/10.1242/jeb.037523

Pörtner, H.-O., Knust, R., 2007. Climate change affects marine fishes through the oxygen limitation of thermal tolerance. Science, 315, 95-97. https://doi.org/10.1126/science.1135471

Simčič, T., 2005. Respiratory electron transport system (ETS) activity and respiration rate in cold-stenothermal and eurythermal chironomid larvae from highmountain lakes. Archiv für Hydrobiologie, 162, 399-415. https://doi.org/10.1127/0003-9136/2005/0162-0399

Simčič, T., Brancelj, A., 1997. Electron transport system (ETS) activity and respiration rate in five Daphnia species at different temperatures. Hydrobiologia, 360, 117-125.

https://doi.org/10.1007/978-94-011-4964-8_13

Simčič, T., Lukančič, S., Brancelj, A., 2005. Comparative study of electron transport system activity and oxygen consumption of amphipods from caves and surface habitats. Freshwater Biology, 50, 494-501.

https://doi.org/10.1111/j.1365-2427.2005.01339.x

Simčič, T., Pajk, F., Brancelj, A., 2010. Electron transport system activity and oxygen consumption of two amphibious isopods, epigean Ligia italica Fabricius and hypogean Titanethes albus (Koch), in air and water. Marine and Freshwater Behaviour and Physiology, 43, 149-156. https://doi.org/10.1080/10236244.2010.483052

Simčič, T., Jesenšek, D., Brancelj, A., 2015. Effects of increased temperature on metabolic activity and oxidative stress in the first life stages of marble trout (Salmo marmoratus). Fish Physiology and Biochemistry, 41, 1005-1014. https://doi.org/10.1007/s10695-015-0065-6

Simčič, T., Sket, B., 2019. Comparison of some epigean and troglobiotic animals regarding their metabolism intensity. Examination of a classical assertion. International Journal of Speleology, 48(2), 133-144. https://doi.org/10.5038/1827-806X.48.2.2251
Sket, B., 2008. Can we agree on an ecological classification of subterranean animals. Journal of Natural History, 42, 1549-1563.

https://doi.org/10.1080/00222930801995762

Statistical office RS, 2018. Average annual and monthly air temperatures $\left({ }^{\circ} \mathrm{C}\right)$ by meteorological stations, Slovenia, annual data until 2014 - in Slovene (http:// pxweb.stat.si/pxweb/Dialog/Saveshow.asp) [accessed February 6, 2018]

Trasviña-Arenas, C.H., Garcia-Triana, A., PeregrinoUriarte, A.B., Yepiz-Plascencia, G., 2013. White shrimp Litopenaeus vannamei catalase: Gene structure, expression and activity under hypoxia and reoxygenation. Comparative Biochemistry \& Physiology B, 164, 44-52.

https://doi.org/10.1016/j.cbpb.2012.10.004

Vinagre, C., Madeira, D., Narciso, L., Cabral, H.N., Diniz, M., 2012. Effect of temperature on oxidative stress in fish: Lipid peroxidation and catalase activity in the muscle of juvenile seabass, Dicentrarchus labrax. Ecological Indicators, 23, 274-279.

https://doi.org/10.1016/j.ecolind.2012.04.009

Vranković, J., Borković-Mitić, S., Ilić, B., Radulović, M., Milošević, S., Makarov, S., Mitić, B., 2017. Bioaccumulation of metallic trace elements and antioxidant enzyme activities in Apfelbeckia insculpta (L. Koch, 1867) (Diplopoda: Callipodida) from the cave Hadži-Prodanova Pećina (Serbia). International Journal of Speleology, 46(1), 99-108.

https://doi.org/10.5038/1827-806X.46.1.1981

Wojtal-Frankiewicz, A., Bernasińska, J., Frankiewicz, P., Gwoździński, K., Jurczak, T., 2017. The role of environmental factors in the induction of oxidative stress in zebra mussel (Dreissena polymorpha). Aquatic Ecology, 51, 289-306.

https://doi.org/10.1007/s10452-017-9617-4

Zamocky, M., Furtmüller, P.G., Obinger, C., 2008. Evolution of catalases from bacteria to humans. Antioxidants \& Redox Signaling, 10, 1527-1548. https://doi.org/10.1089/ars.2008.2046

Zou, E., Du, N., Ali, W., 1996. The effects of severe hypoxia on lactate and glucose concentrations in the blood of the Chinese freshwater crab Eriocheir sinensis (Crustacea: Decapoda). Comparative Biochemistry \& Physiology A, 114, 105-109. https://doi.org/10.1016/0300-9629(95)02101-9

Žagar, A., Simčič, T., Carretero, M.A., Vrezec, A., 2015. The role of metabolism in understanding the altitudinal segregation pattern of two potentially interacting lizards. Comparative Biochemistry \& Physiology A, 179, 1-6.

https://doi.org/10.1016/j.cbpa.2014.08.018 